\title{
Architecture Design in Energy Usage Efficiency Effort
}

\author{
Frysa Wiriantari $^{1^{*}}$, Arya Bagus Mahadwijati Wijaatmaja ${ }^{1}$ \\ Architecture Department, Faculty of Engineering, Dwijendra University, Denpasar, \\ Indonesia
}

\begin{abstract}
The current world condition where the availability of energy especially non-renewable energy is running low, we are required to be able to use available energy efficiently and as economically as possible. Amid the not yet socialized use of alternative energy, these demands are mandatory. One key to saving energy is the use of electrical energy to meet the needs of lighting and air conditioning. Some ways that can be done to save energy are through the management of utility systems, user behavior and consistency of knowledge related to energy-efficient buildings. Some of the principles used in energy-efficient development are minimizing fuel, adjusting to the surrounding climate conditions, using appropriate materials, while still providing comfort to the user. The method used in this research is a qualitative descriptive method focusing on efforts to minimize energy use in buildings.
\end{abstract}

Keywords: Energy, renewable, alternative, efficient

*Corresponding Author:

E-mail: maheswarimolek@gmail.com (Frysa Wiriantari)

Architecture Department, Faculty of Engineering, Dwijendra University, Denpasar, Indonesia

\section{INTRODUCTION}

The rapid development of modern technology provides many benefits to human life today. Although it has negative effects resulting from its development. One of them is the trending use of modern technology that is energy consumptive (Biwole, Eclache and Kuznik, 2013). Expert research shows the world's energy use has increased rapidly in recent years. This increase occurred not only in the industrial sector but also in the building sector, ranging from commercial and profit oriented buildings, buildings with educational functions to residential buildings that in some locations even showed significant increase on energy consumption (Mackay, 2008).

A number of studies shows an increase in energy use approximately $5 \%$ to to $10 \%$ each year. The most drastic increase occurred in the United States as the world's largest energy user, which was about three times more in the period between 1950 - 1973 than in previous times (Oliveira, 2007) . Energy consumption in buildings (lighting, air conditioning, elevators, etc.) accounted for nearly a quarter of the world's annual energy supply in the late 80s (Sodagar, Gilroy-Scott and Fieldson, 2008). Nearly two-thirds of it is supplied from oil and gas fuels whose reserve age is not more than 100 years (30 years for Indonesia). This situation is worsening and occurs in developing countries, especially in Southeast Asia including Indonesia (Winne and Wiriantari, 2020). Due to the high pace of economic development that encourages these countries to use largely advanced technology products without thinking about the risk of draining nonrenewable energy sources from petroleum energy (Armaroli and Balzani, 2007).

The emergence of skyscrapers in major cities in Indonesia such as Surabaya 
and Jakarta, where almost the entire body of the building uses glass sheath without being given a barrier to solar radiation causing a greenhouse effect (Sodagar, Gilroy-Scott and Fieldson, 2008). This greenhouse effect does not seem to be something that is a focus for developers and people who are in the world of design (Nareswari and Wiriantari, 2020). Short waves of sunlight entering through the glass wall will turn into long waves once inside the room, and these cannot be transmitted back beyond the glass wall. As a result there is an accumulation of heat in the building. Energy savings through architectural design lead to savings in electricity use, whether for air cooling, artificial lighting, or other electrical equipment in buildings (Wiriantari and Wijaatmaja, 2019) (Milosevic, 2004). How the architecture of the building is such that the room is bright enough without much use of lights and so that the indoor air can cool without the help of an air conditioning machine. How air lighting and cooling can be done naturally without relying on electrical equipment that is consumptive to energy sourced from fuel. With certain design strategies, buildings can modify an uncomfortable external climate into a comfortable space climate without consuming much electricity sourced from fuel (Marques and Loureiro, 2013).

This research is focused on the basic principles that used in the construction of energy-efficient buildings, especially buildings with educational functions and how the concept of energy saving translates into design.

\section{METHODS}

The method used in this study is a qualitative descriptive method.
Qualitative research methods in this case are not based on mathematical logic and numbers or statistic calculation methods. The method of data search using litelature study method is by looking for information about similar studies and research that has been done before on related topics. Internet searching is looking for data in the internet in the form of research websites and others. Interviews of individuals who have competencies in the field of building physics and utilities.

\section{RESULT AND DISCUSSION}

The use of glass material as a building sheath or as atria (atrium) was originally found in sub-tropic countries such as Europe. This is reasonable given that the country needs to pay attention to efforts to suppress energy use for lighting and heating, especially in winter. The heat build-up in the building due to the 'greenhouse effect' provides extra heat and the room gets warm, so the room becomes quite comfortable without the use of a heating machine. This will reduce the use of electricity for the country (Oliveira, 2007)

But on the other hand, the use of building sheaths from glass materials in Indonesia does not seem to give an advantage, this is because the space inside the building becomes hot and requires the conditioning of air conditioning (AC). And what are the consequences? The results are that the energy consumed for cooling gets bigger and swells as the heat that must be 'discarded' becomes greater due to the accumulation of heat in the building as a consequence of the 'greenhouse effect'.

The results also mention that the use of energy (electricity) of buildings 
that have a sun barrier can reach about $30 \%$ to $50 \%$ lower than buildings without a solar barrier to reach the same room temperature. This fact shows the potential to suppress the energy consumption of air conditioning cooling in buildings by preventing the direct heating of the sun against the walls of the building's sheath glass. The idea of Passive Solar Design as tried on the buildings in Europe above can also be applied in Indonesia in different ways. If buildings in Europe are designed to take the heat of the sun in winter and get rid of it in summer, buildings in Indonesia, except in mountainous areas, are expected to get rid of the solar heat all year round and use it only for daylight lighting, to save the use of electric lights. So the walls of glass need to be given a barrier so that the solar radiation from the west-east side does not directly hit the glass sheath, while allowing the indirect entry of sunlight from the north-south side at certain times.

Several buildings in the humid tropical countries have been designed with the concept of "energy efficient architecture", including the Low Energy Building in Putra Jaya Malaysia, and Menara Mesiniaga in Kuala Lumpur. Like all buildings, especially multi-storey buildings, from the beginning of the design process must take into account the energy saving aspect. Energy saving efforts, among others, aim to balance energy production and consumption in buildings. Energy-Efficient Architecture is architecture based on the idea of "minimizing energy use without limiting or changing the function of the building, the comfort and productivity of its occupants" by utilizing cutting-edge science and technology actively.
Some of the ways that can be done to make energy savings are (Karyono, 2016) through the building utility system including lighting, air conditioning and the use of cross ventilation), through the attitude of the user (building user) including discipline for energy saving life, consistency and knowledge of the user and through the design of the building architecture (passive and active system). Passive design is one way to save energy use through passive utilization of solar energy - without converting solar energy into electric energy. Passive design relies more on the ability of architects, how to make the design of the building be able to 'modify' the uncomfortable outer climate conditions into a space inside a comfortable building by itself.

In lighting utility systems for example can be done with the right arrangement of lights adjusted to the location of the windows (natural light sources), the use of artificial lighting is reduced, without having to sacrifice visual comfort. On-off switches need to be considered against light grouping. Rows of lights affixed to ceilings near windows should be grouped into one, while rows of ceiling 'inner' lights that are far away from the windows should be in another group. When the air is clear during the day, groups of lights near windows can be turned off without disturbing the lighting needs of users in the area.

Green Building is one of the alternative that is increasingly popular in the midst of the current environmental quality. The main objectives of green building are sustainable planning, water utilization efficiency, energy efficiency and renewable energy use, protection of natural resources and maintenance of environmental quality in buildings
Journal Homepage:

http://ejournal.undwi.ac.id/index.php/jsds
Copyright (C) 2019 Dwijendra University. All right reserved. 
(Akeiber et al., 2016) . The application of solar energy in architecture is part of an effort to achieve a balance between nature and the built environment. The use of solar energy, for buildings in humid tropics is a contribution to energy conservation in the future. Radiation that goes directly into buildings is avoided in response to climate. However, radiation should also be utilized as an energy source, among others with solar panels placed on the roof or on the facade of the building adapted to the architectural aesthetic. Some of the principles used in energy efficient development are:

1. Energy saving: minimize fuel and electrical energy and maximize existing natural energy (sun as light in the morning to evening)

2. Pay attention to climate conditions: buildings designed should pay attention to the climatic conditions around the site (the site has high rainfall or not)

3. Minimizing resources: the use of building materials taking into account aspects of ecosystem protection and natural resources

4. Respect for site / has no negative implications for the health and comfort of building users

5. Respect for user/ respond to the site condition of the building

6. Apply/use existing principles as a whole
New Media Tower building is one of the buildings with educational function that uses the principle of energy saving, this building is the newest building of Multimedia Nusantara University, designed as an energy efficient building by applying various technologies that make it possible to make energy savings by utilizing natural air to the maximum without reduce comfort. The building area of this NMT Building is about 32 thousand square meters. While the total area of all land owned is 8 hectares, with utilization of 40 percent, or 2.4 hectares built.

The use of double skin technology, which is made of perforated aluminum plates, makes it possible to control the intensity of the light and solar heat entering the room so that the room is quite cold and bright. As a result, the use of air conditioners can be reduced so as to save electricity energy.

The holes also serve for air circulation so that the corridors of the building do not need to use air conditioning but are still quite comfortable. Downstairs which is used as a canteen and student meeting area is made with an open concept using natural air. In addition, the building also maximizes water conservation by recycling waste water for reuse and capturing rainwater so that it is not wasted 
Journal of Sustainable Develpment Science

Vol. 2, No. 2, December 2020, pp. 46-52

e-ISSN: 2715-9140 | p-ISSN: 2722-919X

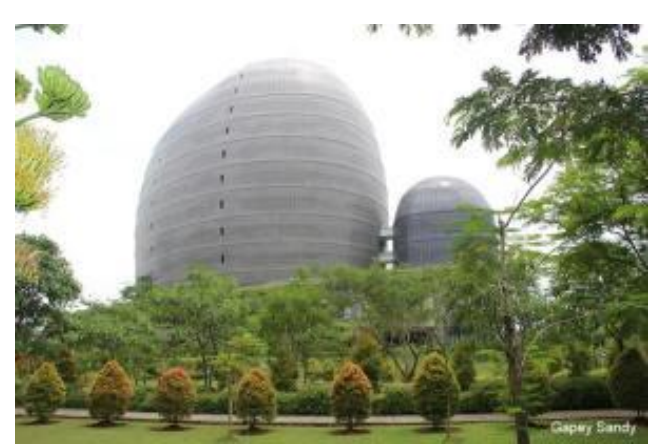

Fig. 1 The exterior of The New Media Tower building owned by Multimedia Nusantara University in Scientia Garden, Boulevard Street Gading Serpong, Tangerang, Banten.

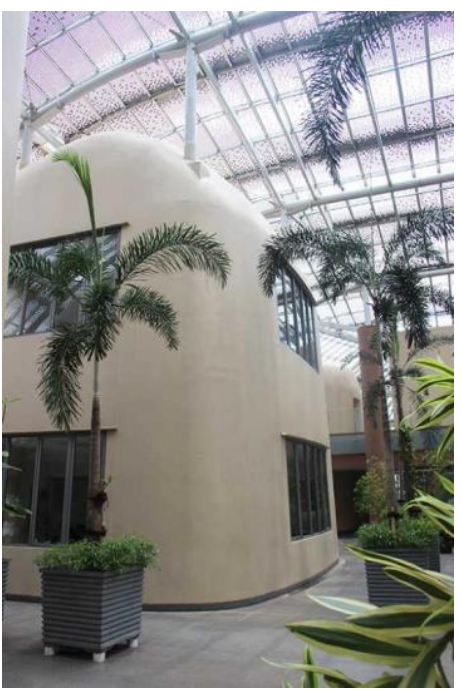

Fig. 2 The atmosphere of the garden and the space, complete with a beautiful open garden. The top is the outer layer cover of the building which is made of aluminum and given holes.

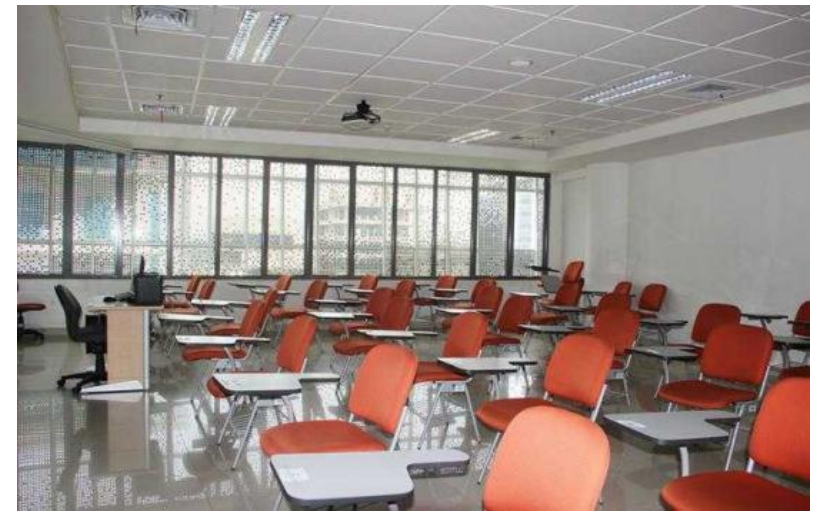

Figure 3. One of the classrooms on UMN Campus that proved not to require much lighting, but was bright enough and not glare in the eyes. So is the room temperature become cool even if the air conditioner is not turned on

\section{CONCLUSION}

The use of buildings that are not friendly with efficiency or that are wasteful of energy will certainly be abandoned by the community, because of the costs that must be incurred by using this building model. It's time for building designers to move towards an energyefficient and environmentally friendly architecture. Indonesia's condition in

\section{Journal Homepage:}

http://ejournal.undwi.ac.id/index.php/jsds
Copyright (ㅇ 2019 Dwijendra University. All right reserved. 
tropic country requires different treatment with sub-tropical climate. So in the form of, and the concept of architectural design is different.

Some of the ways that can be used in suppressing the use of energy in buildings is by 1) preventing the greenhouse effect so that there is no accumulation of heat in the building due to the radiation of the building that will have an effect on air conditioning. The higher the temperature, the more energy used to reach the desired temperature. 2) raise the ceiling of the building and multiply the openings, allowing cross ventilation to emit indoor heat. 3) do not put the core room in the east and west direction, so in this direction put the space between such as stairs, terrace and pantry. 4) provides a barrier against direct sunlight in the core space directly facing the east and west. 5) avoid the use of heat reflective materials.

\section{REFERENCE}

Akeiber, H. et al. (2016) 'A review on phase change material (PCM) for sustainable passive cooling in building envelopes', Renewable and Sustainable Energy Reviews. Elsevier, 60(July), pp. 1470-1497. doi: 10.1016/j.rser.2016.03.036.

Armaroli, N. and Balzani, V. (2007) 'The future of energy supply: Challenges and opportunities', Angewandte Chemie - International Edition, 46(12), pp. 52-66. doi: 10.1002/anie.200602373.

Biwole, P. H., Eclache, P. and Kuznik, F. (2013) 'Phase-change materials to improve solar panel's performance', Energy and Buildings, 62(July), pp. $59-67$. doi: 10.1016/j.enbuild.2013.02.059.

Karyono, T. H. (2016) 'Bangunan hemat energi', (8), p. 40561.

Mackay, A. (2008) 'Climate Change 2007:
Impacts, Adaptation and

Vulnerability. Contribution of Working Group II to the Fourth Assessment Report of the Intergovernmental Panel on Climate Change', Journal of Environment Quality, 37(6), p. 2407. doi: 10.2134/jeq2008.0015br.

Marques, B. and Loureiro, C. R. (2013) 'Sustainable Architecture: Practices and Methods to Achieve Sustainability in Construction', International Journal of Engineering and Technology, (April 2013), pp. 223-226. doi: 10.7763/ijet.2013.v5.547.

Mendra, I. W. and Wiriantari, F. (2016) 'Perubahan Spasial Permukiman Tradisional di Desa Adat Tenganan Pegringsingan Bali', Jurnal Anala, 1(15), pp. 73-97. Available at: https://scholar.google.com/citations.

Milosevic, P. (2004) 'The concept and principles of sustainable architectural design for national parks in Serbia', Spatium, (11), pp. 91-105. doi: 10.2298/spat0411091m.

Nareswari, W. and Wiriantari, F. (2020) 'Penerapan Pendekatan Arsitektur Dalam MerancangaPerpustakaan Umum', Anala, 8(2), pp. 25-32. Available at: http://103.19.229.34/index.php/anala/ article/view/979.

Oliveira, A. C. (2007) 'The energy shift: Towards a renewable future', International Journal of Low Carbon Technologies, 2(3), pp. 289-299. doi: 10.1093/ijlct/2.3.289.

Sodagar, B., Gilroy-Scott, B. and Fieldson, R. (2008) 'Design for Sustainable Architecture and Environments', The International Journal of Environmental, Cultural, Economic, and Social Sustainability: Annual Review, 4(4), pp. 73-84. doi: $10.18848 / 1832-$ 2077/cgp/v04i04/54505.

Winne, S. B. and Wiriantari, F. (2020) 'Arsitektur Rumah Adat Tradisional Mbatangu Di Kampung Ratenggaro', Jurnal Anala, 8(1), pp. 27-34. doi: 10.46650/anala.8.1.934.27-34. 
Journal of Sustainable Develpment Science

Vol. 2, No. 2, December 2020, pp. 46-52

e-ISSN: 2715-9140 | p-ISSN: 2722-919X

Wiriantari, F. and Wijaatmaja, A. B. M. (2019) 'PERUBAHAN BENTUK,

38-49. Available at: FUNGSI DAN STRUKTUR JINENG DALAM ARSITEKTUR TRADISIONAL BALI', in Suaradnyana, K. (ed.) Seminar Nasional Inovasi dalam Penelitian Sains, Teknologi dan Humaniora. Denpasar: Dwijendra University, pp. https://eproceeding.undwi.ac.id/index .php/inobali/article/view/58.

Wiriantari, F. (2016) 'Prosedur pembuatan dan pengujian mutu beton', Anala, 3(1), pp. 1-11. Available at: http://ejournal.undwi.ac.id/index.php/ anala/article/view/200. 